\title{
Associate of Science
}

National Cancer Institute

\section{Source}

National Cancer Institute. Associate of Science. NCI Thesaurus. Code C71344.

An associate's degree awarded upon completion of a course of study usually lasting two years with areas of concentration in mathematics, natural sciences, or technology. 